\title{
LITOESTRATIGRAFIA E PALEOAMBIENTE DO GRUPO SÃO ROQUE NA REGIÃO DE PIRAPORA DO BOM JESUS, SP.
}

\author{
M.Bergman ${ }^{1}$
}

O Grupo São Roque, de maneira ampla, representa a evolução de uma faixa supracrustal vulcano-sedimentar de idade do Proterozóico Superior a Médio, em condições metamórficas da fácies xisto-verde a anfibolito, com padrão de deformação polifásico.

Na região de Pirapora do Bom Jesus, as litologias São Roque ocorrem em grande estrutura sinclinorial tardia, onde a exposição de grande número de estruturas primárias preservadas (sedimentares, organogênicas e ígneas) permite a reconstituição do empilhamento original da seqüência e considerações quanto à paleogeografia e ambientes da Bacia São Roque.

A compartimentação litoestratigráfica proposta para área do Sinclinório de Pirapora foi desenvolvida através de mapeamento geologico de semi-detalhe (1:20.000), e é persistente em linhas gerais para a faixa Jaraguá - Cristais, a E (CARNEIRO, 1983, Mapa Geológico 1:20.000), bem como para os terrenos São Roque a W, na Folha Cabreúva (SANTORO, 1984, Mapa Geológico 1:50.000).

São definidas três unidades litoestratigráficas:

. Unidade vulcanossedimentar basal, representada por uma pilha estratificada de rochas vulcânicas a sub-vulcânicas de caráter básico toleítico, com estruturas e microtexturas ígneas preservadas ("pillow-lavas", texturas blasto-glomeroporfiríticas, blastofíticas e outras), que alternam bancos métricos de rochas bandadas a laminadas, de composição mineralógica em

\footnotetext{
${ }^{\mathrm{I}}$ Departamento de Geologia Geral, Instituto de Geociências/USP, São Paulo.
} 
parte comum, atestando prováveis depósitos piroclásticos aquagênicos derivados de detritos de rochas básicas. Rochas carbonáticas, como calciofilitos, metadolomitos e metadolomitos estromatolíticos têm associação com alguns corpos da unidade vulcânica.

. Unidade clástica turbidítica superior, com contatos transicionais com os carbonatos anteriores. Apresenta na base fácies arenosas, com meta-conglomerados monomíticos finos gradados, metarenitos quartzosos, e predominância de intervalos $\mathrm{Ta}$, Tb e Tc, gradando em direção ao topo para fácies pelíticos, com intervalos Td, Te e Th, e recorrências esparsas de intervalos Ta.

. Unidade clástica alóctone, constituída por espesso pacote de metarenitos arcoseanos com matriz, e por numerosas intercalações métricas a sub-métricas de rocha vulcânica félsica. Cavalga a unidade turbidítica.

Os metacórseos têm, como estruturas sedimentares predominantes na base do pacote, estratificações cruzadas sub-métricas a decimétricas, de ângulo médio. As intercalações vulcânicas compõem a parte média do pacote e são freqüentemente vesiculadas, com estruturas de fluxo nas vesículas.

Acima, e intercalando os últimos corpos félsicos, predominam nos metapsamitos estratificações cruzadas de baixo ângulo, laminação e bandamento plano-paralelo com lâminas gradadas, e bancos sub-métricos com laminações a hematita. Ainda ocorre um espesso nível de ortoquartzitos pobres em estruturas, capeando toda a coluna.

A Bacia São Roque, exposta na Região de Pirapora, é compreendida como um ambiente marinho com fácies de águas relativamente profundas, onde o tratamento geoquímico obtido das análises de rochas básicas disponíveis na literatura geológica (LAZZARI, 1987 e GOMES et al., 1964) aponta para o campo dos basaltos toleíticos de fundo oceânico.

O formato oval dos corpos anfibolíticos a "pillow-lavas" de Pirapora do Bom Jesus e da Vila Lolli, bem como o arranjo de recifes carbonáticos biogênicos (ou tálus de recifes) nos seus bordos, sugerem a ocorrência de edifícios vulcânicos que constituíam altos no fundo oceânico.

A unidade clástica superior é interpretada como de ambiente marinho profundo, com aportes turbidíticos proximais a distais.

A unidade alóctone representa seguramente sedimentação de águas mais rasas, não se excluindo a possibilidade de um ambiente continental costeiro para os ortoquartzitos e para os metacórseos com estratificações cruzadas de ângulo médio.

A grande quantidade de vesículas nos felsitos atesta ambiente sub-aéreo ou 
sub-aquático muito raso, e as estruturas predominantes no pacote arcoseano acima das intercalações vulcânicas situam-no como provável sedimentação de praia.

Pontos importantes na composição e na textura dos meta-arcóseos devem ainda ser esclarecidos, para refinar a compreensão ambiental da seqüência, como a origem da matriz (primária ou introduzida) e a natureza dos feldspatos (detríticos ou neoformados).

\section{REFERÊNCIAS BIBLIOGRÁFICAS}

CARNEIRO, C.D.R. (1983) Análise Estrutural do Grupo São Roque na Faixa entre o Pico do Jaraguá e a Serra dos Cristais, SP. São Paulo. 155p. (Tese de Doutorado, Instituto de Geociências/USP).

GOMES, C.B.; SANTINI, P.; DUTRA, C.V. (1964) Petrochemistry of a Precambrian Amphibolite from the Jaraguá Área, São Paulo, Brazil. Journal of Geology, 72(5):664-680.

LAZZARI, M. de L. (1987) O Metabasito de Pirapora do Bom Jesus, SP. São Paulo. 96p. (Tese de Mestrado, Instituto de Geociências/USP).

SANTORO, E. (1984) Geologia da Folha Cabreúva, SP. São Paulo. 114p. (Tese de Mestrado, Instituto de Geociências/USP). 